\title{
Traversing New Theoretical Frames for Intercultural Education: Gender, Intersectionality, Performativity
}

\author{
Zelia Gregoriou $^{1}$ \\ ${ }^{1}$ Department of Education, University of Cyprus, Nicosia, Cyprus \\ Correspondence: Zelia Gregoriou, Department of Education, University of Cyprus, P. O. BOX 20537, Nicosia \\ 1678, Cyprus. Tel: 357-2289-2931. E-mail: gregoriou@ucy.ac.cy
}

\author{
Received: December 23, 2012 Accepted: January 4, 2013 Online Published: February 16, 2013 \\ doi:10.5539/ies.v6n3p179 \\ URL: http://dx.doi.org/10.5539/ies.v6n3p179
}

\begin{abstract}
This paper attempts to renegotiate the conceptual and political borders of intercultural education by importing ways of thinking, concepts, aporias and questions relevant to a gendered study of intercultural interactions from theoretical terrains outside the disciplinary borders and discursive limits of intercultural education. A number of theoretical developments in disciplines and area studies committed to a politics of justice beyond identity politics pose the need for rethinking the heading of intercultural education. These developments include: the prevalence of the concept and methodology of intersectionality in migration, gender and ethnicity studies; a concern across various kinds of social and political inquiry for the 'culturalist emphasis'; poststructuralist theorizations of power, subjectivity and resistance; and, finally, the urge to re-politicize the study of intercultural interactions. The need to rethink intercultural education emerges with regards to curriculum and pedagogy, policy frames and research methodology. This paper proposes a critical appraisal of 'the ordinary' in intercultural interaction and the charting of new terrains for intercultural education under three headings: transferring insight from the theoretical and methodological engendering of migration studies towards the engendering of school ethnographies and framings of intercultural interactions; de-racializing and re-racializing, de-genderizing and re-genderizing the analysis of student interactions and systemic aspects of ethic/gender school marginalization; and, bringing performativity in the analysis of racialized and gendered school subjectivities, arenas and practices.
\end{abstract}

Keywords: intercultural education, migration, gender, intersectionality, engendering, performativity, Butler

\section{Introduction}

Introducing a gender perspective to the research on multicultural schools and intercultural educational interfaces means overcoming the usual understanding of gender as inclusion of the variable sex or intensifying the comparison of what boys and girls do across the axis of ethnicity. Our attempt to engender the study of intercultural education builds on three areas of research. First, we review how the engendering of migration studies has developed over the last years (Hondagneu-Sotelo, 1999; Mahler \& Pessar, 2006; Piper, 2006; Jones, 2008). Second, in order to prevent a possible conflation of engendering with focusing on differences between migrant boys and migrant girls we explain the meaning of the theoretical shift from gender as identity to gender as performance and from expression to repetition (Butler, 1990; Youdell, 2004; 2005; Davies, 2006). Third, in order to avoid the trap of cultural essentialism, the idealization of difference and the reification of cultural identity we reiterate the interpretive turn in the theory of culture (Geertz, 1973) while, at the same time, addressing the multiple quests in the academic field to politicize intercultural educational by contextualizing the discussion of cultural difference in the context of national politics, global inequality, race and migration (May, 1999, Gilroy, 2006, Gorski, 2006; Gregoriou \& Chistou, 2011; Gregoriou, 2013).

Bringing performativity in the study of power relations and positionalities in and around schools which school subjects inhabit is a theoretical and methodological move that enables us to recognize ambiguity with regards to both agency and subjection to power. There are moments of ambiguity when students and teachers are hailed by dominant discourses (e.g., addressed by ethnic/gender names; asked to give account of themselves as others or as other-ed; feeling the need or given the chance to defend, merge with, or decry the nation; hailed to acknowledge multiculturalism as 'a good thing' and racism as 'a bad thing'). Moments of such ambiguous positionings implicate opportunities for the performative to break from context and for subjects to inhabit defiant positionings in discourse, but also opportunities for the reification of defiant gestures and the recuperation of dominant norms 
and power relations.

\section{Engendering Intercultural Education: Insights from Migration Studies}

In a critical genealogy of gender in migration studies, Mahler and Pessar (2006) note that, beginning in the 1970s, the dearth of research on women was replaced by a "a flurry of historical and contemporary studies that took women migrants as the primary subject of inquiry" (p. 28) and many other studies that incorporated "gender" by inserting the variable of sex into their quantitative data collection. This kind of interest in women migrants, however, did not amount to the engendering of migration studies. In a critical appraisal of the literature, conducted in the late 1990s, Hondagneu-Sotelo (1999) points out that "the vast majority of immigration studies are still conducted as though gender relations are largely irrelevant to the way the world is organized" (p. 566). Hondagneu-Sotelo notes the proliferation of works on women migrants as a category but makes the cautionary remark that a dynamic and fluid conceptualization of gender as relational and situational is still missing. This is how she outlines such a conceptualization of gender:

Gender is not simply a variable to be measured, but a set of social relations that organize immigration patterns. The task, then, is not simply to document or highlight the presence of undocumented women who have settled in the United States, or to ask the same questions of immigrant women that are asked of immigrant men, but to begin with an examination of how gender relations [which are exercised in relational and dynamic ways] facilitate or constrain both women's and men's immigration and settlement (Hondagneu-Sotelo, 1994, p. 3).

Mahler and Pessar (2006) acknowledge the contribution of poststructuralist approaches to the shift from the comparison of gender roles to more dynamic and fluid conceptualizations of gender. As they point out, conceptualizing gender as a process yields a more "praxis-oriented perspective" (p. 29) wherein gender identities, relations and ideologies are fluid, not fixed. But, re-iterating Ferree et al. (1999), they add a crucial caveat to this appraisal of poststructuralism's contribution: gender should also be understood "simultaneously as a structure, that is, a latticework of institutionalized social relationships that, by creating and manipulating the categories of gender, organize and signify power at levels above the individual" (Ferree et al., 1999, p. xix). The recommendation to theorize gender as situational and procedural in tandem with the cautionary remark not to dismiss structures is adopted in their own work. In their earlier research the same authors advocate "gendered geographies of power" (Pessar \& Mahler, 2001) as a framework for grasping and analyzing people's gendered social agency given their positionings within multiple hierarchies of power which operate within and across multiple terrains. This framework, they suggest, allows the study of gender as envisioned and practiced within and across different scales and transnational spaces while, at the same time, acknowledges and accommodates the inconsistencies and contradictions across these spaces. (Note 1)

Intersectionality is another approach that addresses the multiple, multi-sited and interlayered realities and social inequalities of migration as a gendered experience (Lutz, 1997; Hirsch, 1999; Anderson, 2000; Parreñas, 2001; 2005; Yeates, 2005). By examining the ways in which gender, race and nation intersect in migration contexts, a number of new studies map new forms of marginality as well as new forms of agency. The application of intersectionality in migration studies brings up the need to rearticulate and re-emphasize intersectionality's meaning beyond an additive understanding of either marginalities or identities. Terms such as "double-disadvantage", "multiple jeopardy", "triple oppression", etc are suggestive of an understanding of intersectionality as accumulation or synergy. Building on the 1990's scholarship from Black Women's Studies, researchers deploying the various definitions of intersectionality provide various definitions of intersectionality: Crenshaw's (1991) definition of interlocking systems of oppression; Collins' (1990) conceptualization of interwoven patterns of inequality as a "matrix of domination"; Shields's (2008) framework of "mutually constitutive relations among social identities"; Yuval-Davis' (2006) conceptualization of the "ways multiple identities converge to create and exacerbate women's subordination."

These rhetorical articulations of intersectionality, especially when they are separated from their original context, tend to overemphasize the "mutually constituting" character of social identities while downplaying the locality and location of intersectionality. (Note 2) In other words, intersectionality is framed as a condition innately joint to marginality. For example, ethnicity and gender are seen as essentially intersecting and mutually reinforcing conditions (to be a girl means having to deal with stereotypes; to be a migrant girl means having to deal with twice as many stereotypes or/and twice as strong kinds of oppression). This exegesis of intersectionality downplays the way marginality and marginalization, empowerment and subjection, lie and operate with and within 'sites' of practice rather than with and within identity. The elimination of the disjunctures of global 'scapes' (Appadurai, 1996) from the analysis of migration comes to serve neocolonial rationalities. Anna C. Korteweg's research in the Netherlands $(2005 ; 2006)$ illustrates how misreadings of marginality, augmented by 
the systematic absence of attention to the operations of structural and political intersectionality, can provide groundings for very problematic integration policies (for example, jumping to the conclusion that in conditions of migration, ethic fundamentalism and female subordination reinforce each other; attributing female migrant marginality to ethnic/Islamic fundamentalism; considering female subordination and Islamic fundamentalism as interchangeable symptoms of immigrants' failure/resistance to become integrated). In her research Korteweg examines how gender differences have been managed both by emancipation and immigrant integration policies in the Netherlands. She argues that policy makers seem to reinforce those perceptions of gendered practices of minority women and girls that have given rise to calls for strong forms of assimilation. She cites as an example the way new language and cultural competency requirements for new immigrants in the Netherlands are informed by the belief that gender differences are a major obstacle to immigrants' ability to integrate into Dutch society (Korteweg, 2005).

Stuart Hall (1996) develops a more dynamic formulation of intersectionality that avoids the trap of reinforcing perceptions of gendered ethnicity. Hall's formulation of intersectionality explores how systems of oppression "articulate" with one another. As Collins (1998) observes, certain ideas and practices surface repeatedly across multiple systems of oppression and serve as "focal points or privileged social locations" for these intersecting systems of oppression. The search for such "focal points" or "privileged social locations" implicates the expansion of school based field work beyond classroom observation and student interviews. Searching for "customary", "normal" and "neutral" focal points that re-produce patterns of exclusion, researchers would have to study both formal and informal school practices; policy document but also discourses; pedagogies but also habits of learning; axes around which meaning is produced, contested or dispersed; values becoming redefined or devalued; 'trivial' entities becoming resignified; and ordinary procedures reinaugurated in new forms of control or resistance.

In conclusion, we could say that Pessar and Mahler's (2001) framework of transnational geographies of power combined with Hall's notion of "articulate" systems could help us delineate settings, arenas, processes and dominant discourses in multicultural schools as privileged sites of intersectionality and explore with regards to these how and with which effects "gender is racialized and race is gendered" (Glenn, 2002). This framework of gendered transnational geographies of power would be particularly useful for the study of migrant students for a variety of reasons. The gender imaginary of and for migrant children and adolescents is almost always examined within national geographies. Also, the focus of analysis is often placed on transgenerational value conflicts between migrant children and their parents (this might also be a result of the focus of intercultural research on second generation migrant children). One of the dynamic aspects of Pessar and Mahler's framework of "gendered geographies of power" is that it understands gender as a multitude and multi-sited: "gender operates simultaneously on multiple spatial and social scales (e.g., the body, the family, the state)" (2001, p. 445). Transferred to the study of sites and terrains of schools and schooling, the framing of gender as a multitude could provide unique insight for the theorization of intersectionality in intercultural education. Both migration studies and intercultural education studies that focus on migrant students often examine how gender values are defined by migrant parents/community in the home and in the family, and how these are negotiated when migrant children come into contact with other or the dominant other's (majority's) culture/s at school. But what if gender is not that stable when it operates across different sites? As Mahler and Pessar (2003) point out, "when gender is envisioned and practiced within and across different scales and transnational spaces, we often find examples of inconsistencies and contradictions" (p. 822). In other words, the operations of gender in school settings should not be understood in terms of distance vs proximity and conflict vs harmony with regards to migrant family values. Rather, the operations of gender across various sites, subject positionalities and practices should be understood in terms of consistency and inconsistency, continuity and discontinuity, conflict and negotiation. To phrase this within Judith Butler's theory of the performative constitution of the subject, we could say that gender is not merely 'extended' from familial (home) ethic/gender identity into school identities but, rather, is 're-played' and 're-enacted' in school settings, arenas and interactions. Of course, this would also implicate a revised framing of school practices and rituals. These practices and rituals are not merely contested or confirmed, defied or obeyed by migrant students.

\section{Racializing and Engendering Research on Migrant and Ethnic Students: Intercultural Interactions as Sites of Intersectionality}

The notion that gendered practices are symbolic markers of ethnicity is a fundamental premise in research on migrant children and adolescents. Whether it is girls or boys who bear the burden of ethnic markers and the co-construction of gender, whether this is a burden of identity or a process of subjectivation, whether the disciplining of these markers is continuous or discontinuous, research questions would have to reframe 
intercultural interactions as sites of intersectionality.

A number of studies have adopted a comparative approach to the gendered experiences of boys and girls and examine how values and conditions in the receiving society influence parental expectations of gender-related roles. Reviewing research findings for immigrants originating from a number of sending countries, Suárez-Orozco and Qin-Hilliard (2004) note that compared with their brothers, immigrant girls tend to have many more responsibilities at home. Their research findings show, for example, that girls are significantly more likely to report responsibilities for cooking and childcare. The same authors also mention in their literature review that immigrant parents place much stricter control over their daughters' activities outside the house than their sons' (particularly with regards to dating). Similar studies report that immigrant girls are often not allowed to go to parties, spend time with friends after school, or participate in after-school programs and other activities that immigrant boys can typically choose to do freely (Olsen, 1997; Suárez-Orozco \& Qin-Hilliard 2004). Our literature review, however, suggests that immigrant girls are not always inconspicuous repositories of the imperative for cultural continuity. Some researchers suggest that immigrant girls are more likely than immigrant boys to act as transcultural mediators while some others suggest that immigrant girls are socialized by their parents to become bearers of tradition.

Research along the first line of analysis stresses that immigrant girls are more likely than boys to develop "additive" or "hyphenated identities" and to support attempts to bridge "the two cultures" (Qin, 2006). (Note 3) Similarly, Rumbaut (1996) and Olsen (1997) report that immigrant girls are more likely than boys to choose "additive" or "hyphenated identities," while Qin (2006) notes that girls are more likely to attempt to bridge "the two cultures" (Qin, 2006, p. 14). With an increasing number of researchers agreeing that cultural assimilation has negative effects on the psychological health and educational achievement of ethnic students, the combination of parental control (ethnic component) and adjustment to school climate (assimilation component) comes to be perceived as an instance of successful segmented assimilation because it leads to academic achievement. (Note 4) The same line of analysis suggests that the boundaries between ethnic identities appear to be less fluid and less permeable for immigrant boys than for immigrant girls. Boys are reported to have more difficulty in assuming bicultural competencies and making successful bicultural adjustments. There seems to be more alignment between schooling and femininity while masculinity and schooling are perceived as oppositional (Qin, 2006, p. 14).

In contrast to this line of analysis, the second line of analysis portrays immigrant girls as captives of the familial duty for ethnic continuity. Terms and phrases such as Espiritu's "double standards" (Espiritu, 2001) and Billson's "keepers of the culture" (Billson 1995) have become frequent topoi in the study of migration and its impact on girls. These topoi are used metonymically to depict immigrant parental control over immigrant daughters' sexuality. This divergence in findings (immigrant girls as cultural mediators vs immigrant girls as captives of culture) can partly be attributed to the rules of academic writing, the formalism of the genre and the performance rationality that often regulates the framing, size, style and de-contextualizing character of literature review in academic writing. Because gender is not just an organizing axis of cultural values but also a register through which researchers make sense of cross-cultural interpretations, there is a tendency to organize findings on immigrant children across the gender axis while downplaying the context of interactions, the sites of structural intertextuality and the impact of political intersectionality. For example, Espiritu's (2001) findings on the parental treatment of immigrant girls as bearers of tradition are heavily cited in literature on immigrant children and adolescents. Focusing on the relationship between US Filipino immigrant parents and their daughters, Espiritu suggests that "the virtuous Filipina daughter," partially constructed with regards to conceptualizations of the white women as sexually immoral, is a key referent in the construction of immigrant identity and a vehicle for racialized immigrants' redemptive assertion of cultural superiority over the dominant group. In various literature reviews that cover Espiritu's research, this specific finding is overemphasized while the specificity of Espiritu's focus on Filipina girls in the US is sidestepped. Another aspect of Espiritu's research that is often sidestepped in literature reviews is the particularity of the study's focus on parental surveillance of children's dating practices. A different analysis of the same data could have led to very different conclusions if dating was framed as a site of heteronormativity. For example, different questions and different axes of analysis would have emerged if both surveillance and dating were framed as sites of intersectionality that rehearse and refresh the links between heteronormativity and national teenage culture (in the US in general and not among US immigrant Filipinos in particular). Most crucial with regards to the reification of gendered ethnicity in uses (and abuses) of Espiritu's findings, is the elimination of the specifically postcolonial theoretical framing that is paramount in Espiritu's textual politics. As Espiritu explains, by exploring how Filipino immigrants characterize white families and white women, she aims "to contribute to a neglected area of research: how the 'margins' imagine and 
construct the 'mainstream' in order to assert superiority over it" (p. 417). (Note 5)

Another dimension that is often missed in misreadings of Espiritu's study is the relevance of theories of citationality and performativity to her research. As illustrated in her analysis, immigrant gender imaginings in the metropolis are staged against colonial co-constructions of sexualized racialized other (in this case, 'Asian') women as morally licentious and uncivilized: "Historically, the sexuality of racialized women has been systematically demonized and disparaged by dominant or oppressor groups to justify and bolster nationalist movements, colonialism, and/or racism" (Espiritu, 2001, p. 416). Furthermore, Espiritu's analysis suggests that the idealization of female chastity as repository of Filipino tradition in the US is also connected to the contemporary neo-colonial order of the world and the trafficking of sex desire in this context. She notes that the symbolic disowning of the Filipina "bad girl" is staged not only against colonial imaginings of the female exotic body but also against the contemporary trafficking of sex-desire in zones of neo-colonial control such as military bases: "Cognizant of the pervasive hyper-sexualization of Filipina women, my respondents, especially women who grew up near military bases, were quick to denounce prostitution, to condemn sex laborers, and to declare (unasked) that they themselves did not frequent "that part of town" (Espiritu, 2001, p. 426).

The theoretical and methodological insights to draw from this analysis for intercultural research methodologies are multilevel. The double disciplining of daughters by immigrant and ethnic minority families (daughters disciplined as racial/national subjects and as gendered subjects) and immigrant imaginings of "female chastity" must be explored not only with regards to immigrant politics of holding onto traditional values (Note 6) but also against the background of historical relations of oppression and contemporary neo-colonial economies of sex desire, patriarchy and national longings. Context matters and, as Espiritu's research suggests, those who can unravel the historical webs and understand the politics of gendered ethnicities are usually the ones positioned as subordinate objects of intercultural study than as subjects of insubordinate historical analysis. Furthermore, as in the case of Espiritu's study, most studies on gendered ethnicities focus on family life (often conflated with familial rule), parental views of children's dating practices, and parental views of children's academic achievement. What we do not find in current literature is how these imaginings of gendered ethnicities are staged and restaged in school contexts. If gender operates, then we need to see this gendering of ethnicity operating in intercultural settings. We also need to see how children and adolescents construct their subjectivities by negotiating the possibilities and limits of gendered and racialized practices in schools.

Usually the gender questions addressed by the relevant literature on intercultural education are framed around boys or girls: Why do immigrant girls outperform boys in education settings and have higher educational and future aspirations? Why do girls manage to negotiate the conflicting demands of different cultures and split expectations though "segmented accommodation" despite the close parental ethnic monitoring of their behavior? Why does "ethnic separation" appear to overlap with the development of repugnant masculinities? The two theories most frequently used to explain the development of ethnic identity by immigrant and minority students are Ogbu's theory of "oppositional identity" (Fordham \& Ogbu, 1986; Ogbu, 1991) and Suarez-Orozco's theory of social mirroring (Suarez-Orozco, 2004). Teasing the limits of these theories, the kinds of research we review below, examine how constructions of gender identity intersect with (rupture or enhance) processes of racialization. Their focus is on gendered negotiations of racializing practices rather than on individuals' psychological responses to structural inequalities.

Lopez $(2002 ; 2003)$ examines the race-gender gap in education among the children of the Caribbean immigrants (the largest new immigrant group in New York City), placing the intersection of race and gender in high school settings at the center of her analysis. Although both young men and young women had concrete experiences of gendered racialization - men stigmatized as 'hoodlums', women discredited as sexually promiscuous 'mamasitas' and 'welfare queens' - the latter reported fewer problems with teachers at school. Ogbu's theory of oppositional identity turns out to meet its limits not only because it cannot explain this gender variation but also because it is grounded on a modernist notion of subjectivity which localizes the origins of racialization (including processes of oppositional identity formation) in individual psychic mechanisms (e.g., immigrant youth's dismissive attitudes towards schooling, which they perceive as connected to mainstream culture). Lopez's research centers on how institutional practices and classroom pedagogy contribute to or interrupt oppressive racializ(ing) and gender(ing) processes in high school settings. In her fieldwork she finds that "the same so-called 'oppositional' behaviour" from young women is not sanctioned "as harshly" as that of young men and that both men and women teachers are generally more lenient towards young women who transgress school rules, are late to class, and miss homework, than they are towards young men (Lopez, 2003, p. 75). In a similar study, Lopez (2002) finds that seemingly gender neutral practices such as authoritative teaching and guard patrolling are actually informally directed toward young men, thus further racializing those from racially 
stigmatized groups and increasing their alienation from school. (Note 7)

Very similar to Lopez's are the research questions and findings of Qin-Hilliard (2003). Qin-Hilliard's study indicates that immigrant minority girls do better in school and are more academically oriented than immigrant minority boys, especially towards the later years of school. The working hypothesis for this gender difference is that girls may be protected from risk factors such as harsh school environment by a supportive network of teachers, peers and parents while boys are more likely to be negatively influenced by their friends. In this case, Suarez-Orozco's theory of social mirroring also turns out to have a limited applicability in explaining the interaction between racialization and genderization. If parents and teachers have the same academic expectations from boys and girls, how come girls do well and boys do not? Interestingly, in Qin-Hilliard's study the strict parental control of girls is framed as part of the "protective network of supportive relations" as well as part of "a form of social capital" which can be instrumental in promoting educational outcomes of immigrant girls. Qin-Hilliard notes that even though boys were exposed to and assimilated into the "prevalent culture" (which is understood by the author as "that of the inner city"), they were still deficient in supportive networks and had low school expectations and low academic achievement. How do we reconcile then Qin-Hilliard's findings with the view that "segmented assimilation" is a condition for successful school performance? If boys preserve their ethnic ties by constructing their gender identities on the basis of ethnic identity and, at the same time, establish bridges to the receiving society's culture by becoming assimilated to prominent youth culture, why doesn't this 'bridging' count as a form of "segmented assimilation"? It appears that not any kind of ethnic culture (preservation pole of segmented assimilation) and not any kind of acquired culture (assimilation pole of segmented assimilation) would count as ideal component of a successful form of "segmented assimilation." A comparative analysis of the research findings reviewed here suggests that "segmented assimilation" is likely to operate as a condition for school success only when it is normalized in accordance with dominant school culture. As Qin-Hilliard argues,

[f]or many immigrant students today, daily exposure and assimilation into urban school and neighborhood environments may lead to downward social mobility. For these students, ethnicity - that is maintaining native culture and language - may play a protective role, shielding them from the negative influences of today's urban America. In regard to their education, immigrant girls appear to benefit from this shield of ethnicity more than their male counterparts (Qin-Hilliard, 2003, p. 106).

Besides the impact of assimilation to street culture, Qin-Hilliard suggests that for immigrant boys, as in the case of minority boys, the construction of a masculine identity - "acting cool and tough" (Qin-Hilliard 2003, p. 105) is also likely to be in conflict with the school agenda:

For immigrant minority boys, their construction of a gender identity was closely linked to their racial and ethnic identity. To be respected among their peers, immigrant minority boys often had to present and emphasize their masculinity at school by acting cool and tough. As a result, teachers, mostly female, may have been likely to perceive immigrant minority boys as having more behavioral problems than girls and likely to view them as more threatening and dangerous than immigrant girls, which may have led them to punish boys more severely. This had a potentially negative impact on their development (Qin-Hilliard, 2003, p. 105).

In a more recent study that focuses on Chinese immigrant adolescents Qin (2009) reports that compared to girls, boys' formation of gender identity faced more "peer pressure" which was channeled into downplaying education and emphasizing nonacademic activities like sports. Similar studies cited by Qin interpret ethnic minority boys' hyper-masculinity as reactionary to and compensatory for their experiences of racism and their development of a bitter awareness that structural inequalities and discrimination are obstacles that cannot be overcome. Qin, however, attributes the exhibition of hyper-masculinity to conflicting cultural expectations experienced by Chinese boys over the construction of gender and academic identities. Caught between, on the one hand, parental anxiety over their becoming 'wild' and pressure to become 'dragons' of academic success and, on the other hand, anxiety not to be perceived as a 'nerd' and experiences of bullying when perceived as such ('nerd'), ethnic Chinese boys negotiate tensions by responding to peer expectations. (Note 8)

Similar to Qin's intersectional approach is Prieur's analysis of Muslim or Southeast Asian youth's "gender remix" in Norway (Prieur, 2002). The term "gender remix" denotes a much more dynamic kind of intercultural process than Qin's notion of "negotiation" (since the latter ultimately means succumbing to the most powerful kind of pressure). Prieur argues that immigrant youth gender constructions cannot be understood solely in the light of cultural influence, as if on a scale running from conformity to parents' culture to conformity to Norwegian culture. There is something really new in the making - new combinations and new creations reflecting the particular social situation of the young people of immigrant origin (Prieur, 2002, p. 53). Prieur uses 
the concept of "gender remix" to explain the making of the hyper-masculine, aggressive masculinities of immigrant youth from Muslim or Southeast Asian countries. Against the dominant interpretation of aggressive immigrant masculinities as forms of gendered auto-ethnicization, Prieur argues that the major sources for this remix are youth entertainment cultures, subcultures and peer group cultural innovations: "The ideas about honor and respect are probably less influenced by the norms and values of the immigrant boys' grandparents' villages than by movies, hip-hop and rap music, by a commercial derivation of black American culture" (p. 71).

Territoriality, honor, friendship, physical toughness and the idealization of the male body are identified as common traits among these subcultures and immigrant youth's culture of hyper-masculinity. Of course, one might pose the question why migrant male youth acquire these and not other traits. After all, the aim of subcultural identifications is differentiation from dominant culture and other peer groups and not the development of hyper-masculinity as such. Although Prieur adopts a cultural studies approach that focuses on the production and fluidity of gender remix, she does not dispose of notions of structural inequality when it comes to explaining this remix's territorialization on bodily practices. The subcultural values and practices that compose immigrant youth's culture of hyper-masculinity, Prieur argues, are not arbitrary but rather constitute a form of reaction to social and economic marginalization. Desai's (1999) research on 'bad Bengali boys' in London and Bourgois' (1996) research on Puerto Rican crack dealers in New York are cited by Prieur as cases of a similar kind of social interceding between youth subcultures and cultural codes of hyper-masculinity.

\section{Bringing Performativity in: Studying Power Relations and Subject Positionalities in Schools}

It is important to pose the question whether accommodation to school norms implicates resistance, transgression or subversion of these norms by either teachers or students. This also implicates a reframing of the research field and the research questions: from the investigation of the psychological and social operations of race and gender forms of identification and othering to an investigation of how gendered and racialized processes of subjectification are reiterated and resignified in school settings. How do we study gender and race in intercultural school contexts as "acts"? In being hailed to subject positions of submission are teachers and students also enabled to occupy positionalities of agency? In most research findings discussed in the previous sections, the authors speak of racialized spaces, gendered geographies, processes of racialization and gendered practices. When it comes to 'measuring' accommodation and resistance to (or deficiency in) accommodation, in either qualitative or quantitative modalities, cultural inquiry is operationalized in the 'usual' fashion: core values are identified and attitudes towards these values are measured; interviewees are presented with possible future scenarios and asked to position themselves; interviewees are presented with value statements and are asked to indicate their agreement or disagreement; and interviewees are prompted to narrate their own and/or others' (significant others') experiences of 'othering'. Following the 'gathering' of data, the content and tropes of narratives of self-ethnicization and hetero-ethnicization are analyzed: do immigrant minority students embrace disown (verbally or symbolically), associate themselves with or de-associate themselves from the 'bad Filipina girl', the 'welfare queens', the 'nerds' and male gangs?

What we are suggesting here is that there seems to be a discrepancy between the theorization of gender as practice and its codification in terms of attitudes, values and beliefs. This last part of the paper focuses on kinds of research which attempt to reckon with the performativity of gender and ethnicity. The theoretical framework of these studies is organized around Butler's definition of the performative: "that discursive practice that enacts or produces that which it names" (Butler, 1993, p. 13); that which produces that which it names; that which enacts its own referent. According to Butler, at the heart of becoming a subject is the ambivalence of mastery and submission which, paradoxically, take place simultaneously - not in separate acts, but together in the same moment:

The more a practice is mastered, the more fully subjection is achieved. Submission and mastery take place simultaneously, and it is this paradoxical simultaneity that constitutes the ambivalence of subjection. Where one might expect submission to consist in a yielding to an externally imposed dominant order, and to be marked by a loss of control and mastery, it is paradoxically marked by mastery itself ... the lived simultaneity of submission as mastery, and mastery as submission, is the condition of possibility for the subject itself (Butler, 1995, pp. 45-46).

The focus on the 'performative' implicates a fundamental shift in the conceptualization of school subjectivities, ethnicity and gender. The latter are seen not as axes of identity but rather as acts of subjectivity, not as acts performed by an already established subject but rather as acts which re-enact the subjectivity of the one to whom the agency of the acts is attributed. The shift from narratives to discourse and from attitudes and values to acts implicates a more fundamental shift: from the sociocultural construction of identity to the discursive production 
of subjectivity. In other words, we do not talk about identities of students and teachers but about the constitution and reconstitution of student and teacher subjectivities.

Here we cite here two examples of research conducted in multicultural schools that exemplify this shift from identity to subjectivity. The first example is cited from Deborah Youdell's (2006) analysis of school events and discourses related to Multicultural Day at Plains High School. The multitutde of these events and discourses is framed by Youdell as "a collective performative interpellation" (p. 522). (Note 9) In what she describes as a "playful skirmish" than a "battle", Lebanese and Turkish students (who have contesting performative claims over the national paternity of a certain stall) organize and staff together the 'Arabic Food' stall under the collective "given and taken" name, 'Arab'. The following event serves as the backdrop for Youdell's deployment of a whole terrain of interrelated performatives though which subjecthood is effected as both subjectivated and subjugated. The Deputy Principal ejects an Arabic boy on a BMX who has spent the afternoon at the stall. The Deputy Principal says to him: "You were going to light up on the premises - now leave." The boy cups an unlit cigarette in his hand. One of the students from the stall asks: "Sir, what if I personally vouch for him?" The Deputy Principal does not respond to this offer and directs the boy away. "The Deputy Principal watches me watching," notes the researcher (Youdell, 2006, p. 520).

By focusing on "collective performative interpellation" rather than on minority students' identity development and cultural conflicts experienced particularly by these students, the researcher brings forth the ambivalence involved in racializing acts and practices. In constituting 'Arabic' as a legitimate axis of minority cultural difference (thus projecting a multicultural politics of tolerance and, presumably, combating islamophobic exclusion), the school, Youdell argues, subjectivates the Arabic subject as a good student. The students, on the other hand, take up this subjecthood but, in doing so, they also cede the authority of the school and its institutituional force to subjectivate and subjugate the Arabic students. As Youdell puts it, "the students gain the rights of the student (to invite guests) but also subjection to teacher authority (to have their guests ejected)" (Youdell, 2006, p. 522). Youdell attributes the same kind of performative ambivalence to school securitization processes. The moment the Arab/Islamist threatens to burst out of the confines of service and the White, male, senior teacher stands in the quad in front of the stall, walkie-talkie in hand, the 'Arabic' students gain public recognition as legitimate and subjectivation opens up the opportunity for self constitution. However, as Youdell adds, noting the subversive performative's limited capacity to break from context and historicity, self-constitution under the aegis of this legitimacy "threatens to slide back into injury and the constraint of the Savage Arab/Islamist threat" (Youdell, 2006, p. 523). (Note 10)

Comparing Youdell's analysis of racialization as subjectivation-and-subjection to Qin's analysis of immigrant minority youth's targeting by school disciplinary practices, we could say that both explicate the productive aspects of racialized and gendered forms of educational inequality and exclusion. There is one significant difference, however, between these two kinds of analysis. By bringing out the discursive character of institutional arrangements and student practices, Youdell is also bringing out their contingent nature. Her analysis suggests that in the context of performative politics, institutional mechanisms can also be understood as discursively mediated. As such, they are not mere tools of control, acting on students, but processes of subjectification, operating with students, though which minority students' discursive agency, albeit precarious and amenable to processes of subjection, is enabled.

The second example is cited from Davies (2006). Davies' analysis of scenes of subjectification in multicultural school contexts elucidates the relevance of Butler's theorization of performativity for the analysis of disobedient citations of gender and ethnicity in school settings. Davies focuses on interactions of teachers with primary school students to illustrate the complex simultaneous processes of recognition on the part of the students: how they take-up and subvert power; how they disavow dependency from the authority of the dominant 'other' to bestow upon them particular kinds of recognition. Davies argues that this disavowal of dependency takes place through the reiteration and repetition of the very discourses through which students are subjected to disciplinary control. In one of the school scenes analyzed by Davies, we watch two boys, who had been involved in a playground fight two days ago, walking down the corridor pass the teacher who had intervened in their fight. They speak pleasantly to her and, while followed by their own teacher who looks angry because they have just been very disruptive in her gym session, move down the corridor, embrace each other and sing to each other (not provocatively, but loud enough for the teacher to hear): "We are the naughty boys ..." (Davies, 2006, pp. 165-166).

Analyzing the performative aspects of this scene, Davies suggests that the two boys "subvert, for the moment, the category of naughty boy, asserting themselves as powerful, and as independent of the teacher's controlling gaze" (p. 428) Davies emphasizes that the boys do not escape the dominating force of the category "naughty 
boys" and their positioning within it. At the same time, as she notes, their subjection to power does not mean that the 'naughty boys' are engaged in a powerless form of mimesis. Instead, she argues, something unintended can take place while the dominant discourse is put "at play." The boys, Davies argues, submit to the teacher's definition of them as naughty, but do not, "apparently", submit to what the teacher regards as "the appropriate emotion of shame, or the appropriate desire to reform": "The definition of naughtiness is prior to them - it is outside of themselves, it is imposed on them and they both take it up, wilfully, and at the same time subvert the relations of power in which the teacher's use of the naughty boy category, intended to rein in their power, is appropriated in an extension of their power" (Davies, 2006, p. 428).

The two examples cited above from Youdell and Davies suggest that in order to study how students and teachers are constituted and reconstituded as racialized and gendered subjects in the context of intercultural interactions, researchers must be able to go beyond self narratives and analyze, in situ, critical moments of racialization and engendering with particular emphasis on the citationality of speech acts and discourse's structure of iterability. More importantly, in order to understand how citationality, repetition and difference create possibilities for the constitution of the race/gender subject to be reworked, researchers would have to familiarize themselves with those dominant discursive processes by which teachers and students are interpellated into the reign of racialed and gendered forms of subjectification. Furthermore, researchers would need to learn how to identify, beyond preconceived notions of structural forms of marginalization and resistance, those discursively mediated intercultural encounters that set in motion subjection, disempowerment, empowerment and the resignification of masculinities and femininities.

\section{Conclusion}

In an epoch of increasing precarity of social sustenance and precariousness of life, migration policies are increasingly becoming attuned to securitization politics and the rationalities of "liquid modernity" (Bauman, 2000). In this context, intercultural education is at risk of becoming complicit with the normalization of new kinds of social control. While multicultural schools, immigrant student integration policies and antiracist school campaigns have become established as privileged sites for research and social intervention, the persistent allure of the culturalist interpretation and the emphasis on gender and ethnicity as identities undercut the possibilities of research in intercultural education to analyze the systemic character of oppression and the discursive character of disempowerment and empowerment.

Furthermore, the rhetoric of intercultural education often becomes co-opted by dominant state and suprastate agendas oriented to the management of migration rather than to the promotion of fundamental rights, justice and democratization of schools. Many theorists have identified this danger and have urged for a re-politicization of intercultural education. Interestingly, while 'bringing race in' is invoked as a radical gesture (mostly because it challenges the reluctance to rethink colonial legacies), 'bringing gender in' is a gesture that remains insipidly uninvoked. When gender questions are raised, these are more likely to be used as heuristic devices for examining the axes of ethnicity's cultural codification and for assessing the non-western non-citizen 'other's' limits of tolerance and integration (Gregoriou, 2011). Turning our attention from culture to discourse and from identities to power remains a vague proposal if it is not also accompanied by theoretical frames the enable us to question what so far goes unnoticed as ordinary and/or as something that 'does not matter' ('matter' in its double sense as signification and materialization) in school intercultural interactions and practices.

This paper has reviewed, compared and analyzed from a critical perspective attempts to re-think, re-name and re-problematize the 'ordinary' aspects of interculturality: engendering the study of migration and its impact; examining how multiple axes of oppression intersect as they operate in school sites and school lives; understanding how becoming a subject in and through intercultural interactions implicates both subjection to power but also opportunities to destabilize dominant discourses; analyzing intercultural encounters as arenas for signification and resignification; examining the discursive and political relevance of school sites for the intelligibility and receptivity of new significations and new power dynamics. A theoretical and methodological disentanglement from reified meanings of difference is not a simple venture, particularly when one considers the epistemic indebtedness of intercultural education to the concept of culture and its ethical indebtedness to the concept of cultural recognition. Indebtedness to culture needs to be critically reappraised as a loan from residual eighteenth century anthropology instead of being conflated with the theoretical and ethical foundations of education. Conceptual loans and discursive continuities need to be genealogically traced, questioned and troubled and reconvened. 'Going native' beyond the disciplinary borders of education, not into other traditional disciplinary homes but into interstitial terrains such as gender and migration studies might provide intercultural education with new theoretical frames. For now, at least, intercultural education is more in need of frames that produce destabilization of difference than frames that facilitate the management of those who carry the burden of 
difference.

\section{References}

Anthias, F., Yuval-Davis, N., \& Cain, H. (1993). Racialized Boundaries: Race, nation, gender, colour and class and the anti-racist Struggle. London: Routledge.

Appadurai, A. (1996). Modernity at Large: Cultural Dimensions of Globalization. Minnesota: University of Minnesota Press.

Bauman, Z. (2000). Liquid Modernity. Cambridge, UK: Polity.

Butler, J. (1990). Gender Trouble: Feminism and the subversion of identity. London: Routledge.

Butler, J. (1993). Bodies that Matter: On the discursive limits of "sex". London: Routledge.

Butler, J. (1995). Conscience doth make subjects of us all. In Depositions: Althusser, Balibar, Macherey and the Labor of Reading. Yale French Studies (no. 88, pp. 6-26). New Haven, CT: Yale University Press. http://dx.doi.org/10.2307/2930099

Butler, J. (1995). Contingent Foundations: Feminism and the question of 'postmodernism'. In S. Benhabib, J. Butler, D., Cornell, \& N. Fraser (Eds.), Feminist Contentions. A philosophical exchange (pp. 35-57). New York: Routledge.

Butler, J. (1997). Excitable Speech: A politics of the performative. London: Routledge.

Butler, J. (1997). The Psychic Life of Power: Theories in subjection. Stanford, CA: Stanford University Press.

Butler, J. (1999). Revisiting bodies and pleasures. Theory, Culture \& Society, 16(2), 11-20. http://dx.doi.org/10.1177/02632769922050520

Collins, P. H. (1990). Black Feminist Thought: Knowledge, Consciousness and the Politics of Empowerment. Boston, MA: Unwin Hyman.

Collins, P. H. (1998). It's all in the Family: Intersections of Gender, Race, and Nation. Hypatia, 13(3), 62-82. http://dx.doi.org/10.1111/j.1527-2001.1998.tb01370.x

Collins, P. H. (1999). Black Feminist Thought: Knowledge, Consciousness, and the Politics of Empowerment. New York: Routledge.

Crenshaw, K. (1991). Mapping the Margins: Intersectionality, identity politics, and violence against women of color. Stanford Law Review, 43(6), 1241-99. http://dx.doi.org/10.2307/1229039

Davies, B. (2006). Subjectification: The relevance of Butler's analysis for education. British Journal of Sociology of Education, 27(4), 425- 438. http://dx.doi.org/10.1080/01425690600802907

Desai, P. (1999). Spaces of Identity, Cutures of Conflict: The development of new British Asian masculinities. Unpublished PhD Thesis, Goldsmiths College, University of London.

Espiritu, Y. L. (2001). We don't sleep around like white girls do: Family, culture, and gender in Filipina American lives. Signs: Journal of Women in Culture and Society, 26(2), 414-440. http://dx.doi.org/10.1086/495599

Ferree, M. M., Lorber, J., \& Hess, B. B. (1999). Revisioning Gender. Thousand Oaks, CA: Sage.

Fordham, S., \& Ogbu, J. U. (1986). Black students' school success: Coping with the burden of 'acting white'. The Urban Review, 18(3), 176-206.

Fouron, G., \& Glick Schiller, N. (2001). All in the Family: Gender, transnational migration, and the nation-state. Identities, 7(4), 539-582. http://dx.doi.org/10.1080/1070289X.2001.9962678

Geertz, C. (1973). Thick Description: Toward an interpretive theory of culture. In The Interpretation of Cultures (pp. 3-30). New York, NY: Basic Books.

Gillborn, D. (1990). 'Race', Ethnicity and Education: Teaching and learning in multi-ethnic schools. London, UK: Unwin Hyman. http://dx.doi.org/10.4324/9780203400265

Gilroy, P. (2005). Postcolonial Melancholia. New York, NY: Columbia University Press.

Gorski, P. C. (2006). Complicity with Conservatism: The de-politicizing of multicultural and intercultural education. Intercultural Education, 17(2), 163-177. http://dx.doi.org/10.1080/14675980600693830

Gregoriou, Z., \& Christou, G. (2011). The Dubious Gift/Debt of Integration: Patriarchal regimes, ethnicity and sexuality in the school lives of migrant girls in Cyprus. In Young Migrant Women in Secondary Education: 
Promoting Integration and Mutual Understanding through Dialogue and Exchange (pp. 21-58). Nicosia, Cyprus: University of Nicosia Press.

Gregoriou, Z. (2011). Questioning the Location of Gender. In Young Migrant Women in Secondary Education: Promoting Integration and Mutual Understanding through Dialogue and Exchange (pp. 7-20). Nicosia, Cyprus: University of Nicosia Press.

Gregoriou, Z. (2013). Cosmopolitans ... 'from Here': Heading for an-Other host, heading off the turning into hostage. Wagadu: A Journal of Transnational Women's and Gender Studies (forthcoming).

Hall, S. (1996). Introduction: Who Needs Identity? In S. Hall, \& P. du Gay (Eds.), Questions of Cultural Identity (pp. 1-17). London, UK: Sage.

Hirsch, J. (1999). En el Norte la Mujer Manda: Gender, generation, and geography in a Mexican transnational $\begin{array}{llll}\text { community. American } & \text { Behavioral }\end{array}$ http://dx.doi.org/10.1177/00027649921954930

Hondagneu-Sotelo, P. (1994). Gendered Transitions: Mexican experiences of immigration. Berkeley, CA: University of California Press.

Hondagneu-Sotelo, P. (1999). Gender and Contemporary U.S. Immigration. American Behavioral Scientist, 42(4), 565-576. http://dx.doi.org/10.1177/00027649921954363

Jones, A. (2008). A Silent but Mighty River: The costs of women's economic migration. Signs: Journal of Women in Culture and Society, 33(4), 761-769. http://dx.doi.org/10.1086/528877

Korteweg, A. C. (2005). The management of gender difference and immigrant integration policy in the Netherlands. Paper prepared for SSRC/UCI Summer Institute on Immigration, June 27-30, 2005. Retrieved from http://citation.allacademic.com/meta/p_mla_apa_research_citation/1/0/4/0/2/pages104023/p104023-1.php

Korteweg, A. C. (2006). The Murder of Theo van Gogh: Gender, religion, and the struggle over immigrant integration in the Netherlands. In M. Bodemannand \& G. Yurdakul (Eds.), Migration, Citizenship, Ethnos (pp. 47-66). New York, NY: Palgrave-Macmillan.

Lopez, N. (2002). Rewriting Race and Gender High School Lessons: Second-Generation Dominicans in New York City. Teachers College Record Volume, 104(6), 1187-1203. http://dx.doi.org/10.1111/1467-9620.00201

Lopez, N. (2003). Race-Gender Experiences and Schooling: second-generation Dominican, West Indian, and Haitian youth in New York City. Race Ethnicity and Education, 5(1), 67-89. http://dx.doi.org/10.1080/13613320120117207

Lutz, H. (1997). The Limits of European-ness: Immigrant women in fortress Europe. Feminist Review, 57(1), 93-111. http://dx.doi.org/10.1080/014177897339678

Mahler, S. J., \& Pessar, P. R. (2006). Gender Matters: Ethnographers Bring Gender from the periphery toward the core of migration studies. International Migration Review, 40(1), 27-63. http://dx.doi.org/10.1111/j.1747-7379.2006.00002.x

May, S. (1999). Critical Multiculturalism: Rethinking multicultural and antiracist education. London, UK: Falmer Press.

Ogbu, J. (1991). Immigrant and involuntary minorities in comparative perspective. In M. Gibson, \& J. Ogbu (Eds.), Minority Status and Schooling: A comparative study of immigrant and involuntary (pp. 3-33). New York, NY: Garland.

Olsen, L. (1997). Made in America: Immigrant students in our public schools. New York: The New Press.

Parreñas, R. (2001). Servants of Globalization: Women, migration, and domestic work. Stanford, CA: Stanford University Press.

Parreñas, R. (2005). Children of Global Migration: Transnational families and gendered woes. Stanford, CA: Stanford University Press.

Pessar, P. R., \& Mahler, S. J. (2003). Transnational Migration: Bringing gender in. International Migration Review, 37(3), 812-846. http://dx.doi.org/10.1111/j.1747-7379.2003.tb00159.x

Pessar, P. R., \& Mahler, S. J. (2001). Gendered Geographies of Power: Analyzing gender across transnational spaces. Identities, 7(4), 441-460. http://dx.doi.org/10.1080/1070289X.2001.9962675 
Piper, N. (2006). The Politics of Migration. International Migration Review, 40(1), 133-164. http://dx.doi.org/10.1111/j.1747-7379.2006.00006.x

Prieur, A. (2002). Gender Remix: On gender constructions among children of immigrants in Norway. Ethnicities, 2(1), 53-77. http://dx.doi.org/10.1177/1469682002002001522

Qin, D. B. (2009). Being 'Good' or Being 'Popular': Gender and ethnic identity negotiations of Chinese immigrant adolescents. Journal of Adolescent Research, 24(1), 37-66. http://dx.doi.org/10.1177/0743558408326912

Qin-Hilliard, D. B. (2003). Gendered Expectations and Gendered Experiences: Immigrant students' adaptation in schools. New Directions for Youth Development, 100 (Winter), 91-109. http://dx.doi.org/10.1002/yd.65

Richman, K. E. (2002). Miami Money and the Home Gal. Anthropology and Humanism, 27(2), 119-132. http://dx.doi.org/10.1525/ahu.2002.27.2.119

Richman, K. E. (2005). Migration and Vodou. Gainesville, FL: University Press of Florida.

Richman, K. E. (2008). Innocent Imitations? Authenticity and Mimesis in Haitian Vodou Art, Tourism, and Anthropology. Ethnohistory, 55(2), 203-228. http://dx.doi.org/10.1215/00141801-2007-061

Rumbaut, R. G. (1996). Becoming American: Acculturation, achievement, and aspirations among Children of immigrants. Paper presented at the Annual Meeting of the American Association for the Advancement of Science, Baltimore, MA.

Shields, S. A. (2008). Gender: An Intersectionality Perspective. Sex Roles, 59(5-6), 301-311. http://dx.doi.org/10.1007/s11199-008-9501-8

Suárez-Orozco, C., \& Qin, D. B. (2004). The Cultural Psychology of Academic Engagement: Immigrant boys' experiences in U.S. schools. In N. Way, \& J. Chu (Eds.), Adolescent Boys in Context (pp. 295-317). New York, NY: New York University Press.

Suárez-Orozco, C., \& Suárez-Orozco, M. (2001). Children of Immigration. Cambridge, MA: Harvard University Press.

Suárez-Orozco, C. (2004). Formulating Identity in a Globalized World. In M. Suárez-Orozco, \& D. B. Qin-Hilliard (Eds.), Globalization: Culture \& Education in the New Millennium (pp. 173-202). Berkeley, CA: University of California Press.

Tolman, D. L., \& Higgins, T. E. (1996). How being a good girl can be bad for girls. In N. B. Maglin \& D. Perry (Eds.), Bad Girls/Good Girls: Women, Sex, and Power in the Nineties (pp. 295-317). New Brunswick, NJ: Rutgers University Press.

Waters, M. (1996). The intersection of gender, race, and ethnicity in identity development of Caribbean American teens. In B. J. R. Leadbeater \& N. Way (Eds.), Urban Girls: Resisting stereotypes, creating identities (pp. 65-84). New York, NY: New York University Press.

Yeates, N. (2005). Global Care Chains: A critical introduction. Global Migration Perspectives, 44. Geneva: Global Commission on International Migration. http://dx.doi.org/10.1080/1461674042000235573

Youdell, D. (2003). Identity Traps or How Black Students Fail: The interactions between biographical, sub-cultural and learner identities. British Journal of Sociology of Education, 24(1), 3-20. http://dx.doi.org/10.1080/01425690301912

Youdell, D. (2004). Wounds and Reinscriptions: Schools, sexualities and performative subjects. Discourse:

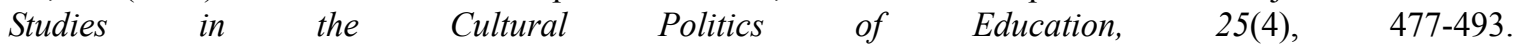
http://dx.doi.org/10.1080/0159630042000290973

Youdell, D. (2005). Sex-Gender-Sexuality: How sex, gender and sexuality constellations are constituted in secondary schools. Gender and Education, 17(3), 249-270. http://dx.doi.org/10.1080/09540250500145148

Youdell, D. (2006). Subjectivation and Performative Politics - Butler thinking Althusser and Foucault: Intelligibility, agency and the raced-nationed-religioned subjects of education. British Journal of Sociology of Education, 27(4), 511-528. http://dx.doi.org/10.1080/01425690600803160

Yuval-Davis, N. (2006). Intersectionality and feminist politics. European Journal of Women's Studies, 13(3), 193-209. http://dx.doi.org/10.1177/1350506806065752

Zhou, M. (1997). Segmented Assimilation: Issues, controversies, and recent research on the New Second Generation. International Migration Review, 31(4), 975-1008. http://dx.doi.org/10.2307/2547421 


\section{Notes}

Note 1. Mahler \& Pessar (2006) cite from Fouron \& Glick Schiller (2001) examples of how patriarchy is both challenged and buttressed by transnational migrants' actions across geographic space and scales of agency. Similar kinds of examples that show the ambivalent deployment of power and agency in transnational trajectories are found in Karen Richman's work (Richman, 2002; 2005; 2008).

Note 2. For an analysis of family as "site of intersectionality" see Collins (1998).

Note 3. Waters (1997) found that Caribbean girls seemed to have more leeway in identity formation than their male counterparts, who tend to face more pressure to form a racial identity due to perceptions of discrimination and unfair treatment from the mainstream society.

Note 4. There is a tendency in the literature to conflate "segmented assimilation" (Zhou, 1997) with "transcultural identity" (Suárez-Orozco \& Suárez-Orozco, 2001), especially in discourses that capitalize on concepts of "immigrant children's development." This conflation is problematized from this paper's approach of radical interculturality because the vision of social justice is completely overshadowed by the ideal of school success.

Note 5. Espiritu explains: "But this strategy is not without costs. The elevation of Filipina chastity (particularly that of young women) has the effect of reinforcing masculinist and patriarchal power in the name of a greater ideal of national/ethnic self-respect. Because the control of women is one of the principal means of asserting moral superiority, young women in immigrant families face numerous restrictions on their autonomy, mobility, and personal decision making" (Espiritu, 2001, p. 417).

Note 6. It is daughters who bear the primary burden of protecting and preserving values both among immigrant families and non-immigrant families. But, as Espiritu puts it, the difference lies in the ways immigrant and nonimmigrant families sanction girls' sexuality. In order to be able to control [their] sexually assertive girls, nonimmigrant parents often rely on the gender-based good girl/bad girl dichotomy (Espiritu, 2001, p. 432): 'good girls' are framed as passive, threatened sexual objects while 'bad girls' are framed as active, desiring sexual agents (Tolman \& Higgins, 1996). Thus immigrant and ethnic minority families come to exercise a 'double disciplining' of daughters: daughters are disciplined as racial/national subjects but also as gendered subjects. In other words, young women who disobey parental strictures are often branded as bad girls but also as "non-ethnic", "untraditional", "radical", "selfish" and "not caring about the family" (Espiritu, 2001, p. 433).

Note 7. Gillborn (1990) argues that the 'myth of an Afro-Caribbean challenge to authority' (for example, a particular way of walking, common amongst African-Caribbean boys in the school) is produced in as much as it is also productive of institutional disciplinarity: "In the day-to-day life of the school almost any display of Afro-Caribbean ethnicity was deemed inappropriate and was controlled, either officially (in the case of non-uniform dress) or informally (in the case of speech or the style of walking noted above)" (p. 29).

Note 8. This cultural conflict does not pre-exist. In a typical national Chinese context, gender identities and academic identities would not be characterized by culturally conflicting codes and values. In such a context, the development of gender identity and the development of national identity, academic identity and national identity, would operate as mutually supportive rather than as antagonistic. Chinese students become ethnic Chinese students because they reside in the interstices of migration.

Note 9. In the course of accepting the Arabic students' donation of an Arabic Food stall, the school constitutes 'Arabic' as a legitimate axis of minority cultural difference and subjectivates the Arabic subject as a good student. In donating the stall and participating in 'Multicultural Day', this 'good-Arabic-student-subject' takes up this school induced subjecthood. Just as the school cedes the good-Arabic-student-subject, the 'good' subject cedes the authority of the school institution by which she/he is subjectivated. Thus, the 'good-Arabic-student-subjects' gain student rights (i.e., the right to invite guests) but also become subjected to teacher authority (to have their guests' suitability assessed and their guests ejected). The stall, the food it sells, and the students and 'others' who staff it, are let into the 'Multicultural Day' by being named first 'Arabic' (Youdell, 2006, p. 522).

Note 10. In another study, Youdell (2003) elicits this performative ambiguity of hegemonic discourses with regards to subcultural bodily practices (e.g., the male Black sub-cultural 'walk'). Youdell argues that bodily acts performed as citations of subcultural status in order to challenge White school hegemony have the potential to recoup the male Black youth as a 'student-child' and subject him to disciplining as an undesirable learner. 